\title{
The Influence of Intention to use Medians Potato Varieties on the Result of Technological Innovation Development with Technology Acceptance Models
}

\author{
Muhammad Hafni Rasyidha, Mukhamad Najib, and Ujang Sumarwan \\ Fakultas Ekonomi dan Manajemen Institut Pertanian Bogor \\ Email: ossirasidda@yahoo.co.id
}

\begin{abstract}
The purpose of this study was to analyze the intention of farmers to use the potato varieties of medians with the development of technology acceptance models (TAM) that combine innovation diffusion theory, subjective norms, self-efficacy, and facilitate conditions to determine the intentions of farmers to use. The method used was a survey with face-to-face interviews with 120 potato farmers. Sampling was taken based on nonprobability sampling using convenience sampling techniques. Analysis of the data used is Structural Equation Modeling (SEM) with the Partial Least Square (PLS) approach. The results show that variables triability, perceived usefulness, subjective norms, and compatibility directly have a positive effect on the intention to use potato varieties medians. While the variables that can be observed, perceived ease of use, perceived self-efficacy, and facilitating conditions do not have a positive effect on the intention to use.
\end{abstract}

Keywords: Intention to Use, TAM Development, SEM - PLS.

\begin{abstract}
Abstrak: Tujuan dari penelitian ini adalah untuk menganalisis niat petani untuk menggunakan varietas kentang median dengan pengembangan model penerimaan teknologi (TAM) yang menggabungkan teori difusi inovasi, norma subyektif, self-efficacy, dan memfasilitasi kondisi untuk menentukan niat petani untuk digunakan. Metode yang digunakan adalah survei dengan wawancara tatap muka dengan 120 petani kentang. Pengambilan sampel dilakukan berdasarkan non-probabilitas sampling menggunakan teknik convenience sampling. Analisis data yang digunakan adalah Structural Equation Modeling (SEM) dengan pendekatan Partial Least Square (PLS). Hasil penelitian menunjukkan bahwa variabel triabilitas, persepsi manfaat, norma subyektif, dan kompatibilitas secara langsung memiliki efek positif pada niat untuk menggunakan median varietas kentang. Sedangkan variabel yang dapat diamati, persepsi kemudahan penggunaan, persepsi self-efficacy, dan kondisi fasilitasi tidak memiliki efek positif pada niat untuk menggunakan.
\end{abstract}

Kata kunci: Niat Digunakan, Pengembangan TAM, SEM - PLS.

\section{INTRODUCTION}

The result of agricultural technology innovations plays an important role in the advancement of the sector in agriculture and are beneficial in improving the lives of farmers. 
This is due to the result of agricultural innovations that are always seeking to increase sources of income and increase agricultural production. One potential commodity that is widely traded in both traditional and modern markets is potatoes. This commodity is known as an alternative source of carbohydrates that can substitute people's food needs. In Indonesia, the supply of potatoes from year to year tends to increase, although it had decreased in 2015 and 2016 by 121 and 122 million tons, in the following year, namely in 2017 experienced an increase again by 130 million tons due to increased domestic production (Bulletin Food consumption, 2017). The supply of potatoes aside from domestic production also comes from imports minus the value of exports. This showed that from 2013 to 2017 the problem of supplying potatoes faced was that the import value was still higher than the export value. This can be seen in Table 1.

Table 1. Development of production, exports and imports of Potatoes in Indonesia in 2013-2017 (million tons)

\begin{tabular}{llccccc}
\hline No & \multicolumn{1}{c}{ Description } & $\mathbf{2 0 1 3}$ & $\mathbf{2 0 1 4}$ & $\mathbf{2 0 1 5}$ & $\mathbf{2 0 1 6}$ & $\mathbf{2 0 1 7}$ \\
\hline & Provision of Potatoes & 1.226 & 1.435 & 1.314 & 1.313 & 1.443 \\
$\mathbf{1}$ & Production & 1.124 & 1.348 & 1.219 & 1.213 & 1.437 \\
$\mathbf{2}$ & Export & 6 & 7 & 7 & 6 & 2 \\
$\mathbf{3}$ & Import & 108 & 93 & 102 & 106 & 80 \\
\hline
\end{tabular}

Source: (Food Consumption Bulletin, 2017)

Also, the average production of potatoes in Indonesia is still considered relatively low when compared to Europe, which averages 25.5 tons per hectare, while the average production in Indonesia only reaches 16 tons per hectare (Food Consumption Bulletin, 2017). The low yield is due to poor quality of seeds, susceptible to virus infection, and lack of post-harvest handling which can cause tuber damage. So that the role of government is needed and the business world to encourage farmers to use or adopt the result of agricultural technology innovation. This is because farmers are both subject and object of agricultural development, the key to success lies with farmers as the main actors in agricultural development (Syakir, 2015).

One of the products of technological innovation for potato commodities from agricultural $R \& D$ institutions is the potato variety medians. This variety is an improvement from Atlantic cultivars with higher productivity, which is 24.9 - 31.9 tons/ha (Suryani et al., 2017). Moreover, other advantages of this potato include disease resistance, high yield tubers have a shelf life resistance, and expenditure for the cultivation of these potatoes is lower compared to other industrial potatoes. The surplus-value possessed by potato medians is expected to be able to stop the import of industrial potatoes.

Garut Regency is one of the regions or areas of vegetable development that is being pursued by the government, especially for the commodity of potatoes. In this region, the potato commodity has the highest harvested area compared to other vegetable crops, reaching 7,894 hectares (BPS, 2017). To increase the use of the Medians potato varieties in Garut Regency, the Agency for Agricultural Research has collaborated with businesses engaged in the development of horticultural seed biotechnology, namely PT. Central Horti Agro Micro Potatoes (CHAMP). The company has been licensed to provide and become a producer of Medians potato seed varieties for national needs. The distribution of potato 
seeds by this company is to groups and members of potato farmers who are willing to cultivate this variety. The leadership of PT. CHAMP revealed that even though the potato commodity had the highest vegetable crop harvest area, currently the medians of potato harvested area used by farmers is only 200 ha or $2.5 \%$ of the overall potato harvest area in Garut Regency. This showed that the low number of potato farmers using varieties of medians.

In this study, an analysis of farmers' intention to use the potato varieties of medians from the result of technological innovations is based on the lack of interest of farmers to use these varieties. The model used in this research is a model called the Technology Acceptance Model (TAM) which is a theory developed by (Davis et al., 1989) that can explain people's acceptance of a particular technology and their opinion of the technology. The current study of the TAM model was developed by adopting a revised technology acceptance model (TAM2) that is integrated with the diffusion of innovation theory and the Theory of Planned Behavior. The original TAM includes Perceived usefulness and Perceived ease of use, a revised technology acceptance model (TAM 2) integrated with the Diffusion of Innovation Theory (IDT) including triability, observability, compatibility, perceived self-efficacy, facilitating conditions, and coupled with direct determinants of behavioral intentions in Theory of Planned Behavior (TPB), namely subjective norms to provide adequate explanations related to the adoption or use of the result of technological innovation.

Based on the introduction above, this study aims to analyze the acceptance intentions of potato farmers and the factors that influence the intention of farmers to use potato varieties medians as the result of agricultural technology innovations triability, observability, perceived usefulness, perceived ease of use, subjective norms, compatibility, perceived self- efficacy, facilitating condition.

\section{THEORETICAL REVIEW}

Technology Acceptance Model. This model developed by Davis et al., (1989) is based on the theory of reasoned action (TRA), which is based on two specific beliefs: perceived usefulness and ease of use so that they are used as benchmarks in technology acceptance. The perceived usefulness is the level at which a person believes that using the system will contribute to achieving certain goals (Davis et al., 1989). While the perception of convenience is a level of one's belief that the use of the system can improve the performance of the work done (Saade and Bahli, 2005).

Further research on TAM, in addition to refining the determinant model of perceived usefulness and perceived ease of use, should discuss the role of other direct determinants of intention to use and behavior and continue to map the main contingency factors moderate the effects of perceived usefulness, perceived ease of use, subjective norms, and other constructions of intentions (Venkatesh and Davis, 2000). The connection, in this case, the intention to use is a form of behavioral tendency to continue to use a system/technology. According to (Lee and Mok, 2013) behavioral intention is the desire of individuals to perform a certain behavior. Many researchers suggested that additional variables should be included in TAM to provide stronger predictive abilities for the model (Legris et al., 2003).

(Venkatesh and Davis, 2000) proposed an update of the TAM known as TAM2. In TAM2, the component's attitude towards usage (which initially mediates some of the effects 
of perceived usefulness and perceived ease of use) is removed from the model, while new variables 'subject norms' are added to capture social influences that force users to use new technology.

Subjective Norms. Subjective Norms are factors derived from the Theory of Planned Behavior (TPB). According to (Ajzen, 1991) the interest is influenced by subjective norm factors in addition to attitude and behavior control factors. Subjective norms are a social element, namely a person's beliefs about what other people think he should be doing, as well as the strength of one's motivation to obey these norms (Fishbein and Ajzen, 2010). In TAM 2 subjective norms are one that reflects three social forces (subjective norms, volunteerism, and image) that are interrelated and impact on customers who face the opportunity to adopt or reject a new system. Someone learns and uses behavior based on what they see in social groups. The observed behavior of others influences the observer imitating that behavior. Social norms play an important role in influencing adoption decisions. In the context of this research, it referred to whether using innovative products based on technology is socially acceptable to farmers and driven by the community.

Innovation Diffusion Theory (IDT). According to (Rogers, 2003), IDT is a theory that is widely used to describe and explain technology adoption, from agricultural tools to organizational innovation. IDT includes five significant innovation characteristics: relative advantage, complexity, compatibility, trialability, and observability. Relative advantage is the extent to which an innovation product can be superior to previous innovation products. Complexity is believed whether innovation is felt difficult to understand and use. The relative advantage is similar to the perceived usefulness, whereas complexity is similar to the perception of ease of use. While compatibility, trialability, and observability are not similar to those two things. Compatibility is the extent to which an innovation is considered consistent with existing values, experience, and the needs of potential adopters. Potential adopters will refuse to adopt an innovation if innovation is not compatible with the values and norms of the social system. Triability refers to the extent to which an innovation can be tested without high initial costs by potential adopters before it is adopted (Hernandez and Mazzon, 2007; Hsbollah and Idris, 2009). While observability is the extent to which the benefits of innovation can be seen by prospective adopters. (Everet and Roger, 2003) considered that potential adopters are likely to use innovation if the benefits of technology have been proven. These five characteristics of innovation resemble TAM, which emphasizes the intention to adopt new technology and psychological influence on individuals (Davis, 1989).

Perceived self-efficacy and facilitating conditions. In particular, the concept of selfefficacy and facilitating conditions have proven to be important factors that influence behavioral intentions and the future use of new technologies (Bandura, 1977; Marakas et al., 2007). Self-efficacy is an idea that describes how an individual evaluates his or her own ability to complete a particular task (Bandura, 1977). Someone can complete tasks and improve performance based on the level of self-efficacy that a person has. In the context of the adoption of potato products medians the result of technological innovation, this perceived efficacy shows how potato farmers perceive their abilities, skills, experience, and expertise needed to achieve success in cultivation. 
Furthermore facilitating conditions are defined as the extent to which an individual believes that satisfactory levels of organizational and technical infrastructure can support the use of the system (Venkatesh et al., 2000). As a fact, this includes environmental factors that help users to use technology more comfortably (Thomson et al., 1991). In the context of potato medians' products, this facilitation condition is in the form of a perspective of farmers' demand, such as training programs, technical consultants, technical guidelines, adequate and appropriate resources related to the needs that can support the use of innovative products.

Effect of triability on Intention to Use. According to (Venkatest et al., 2000) revealed that the variable can be tested (trialability) as an important factor influencing intention to use. (Ajili et al., 2012) in their research showed that triability has a positive effect on the intention to use variable rate irrigation technology. Another study conducted by (Hasan et al., 2018) found that the variable trialability influences consumer intentions to adopt propoor service innovations. Furthermore, (Shiau and Chau, 2015) in their research have different results with research (Ajili, 2012) and (Hasan, 2018). The result showed that the intention to use information technology was not influenced by the variable trialability.

Effect of Observability on Intention to Use. Observability is also a factor that can influence the intention to use (Venkatest and Davis, 2000). Several recent meta-analysis studies found that observability has a strong influence on individuals' intentions to adopt (Arts et al., 2011). While (Shiau and Chau, 2015) in their research also showed that the observability variable had a positive effect on the intention to use or adopt the technology.

Effects of Perceived Usefulness and Perceived Ease of Use on Intention to Use. TAM aims to provide a simple explanation of the factors that determine adoption that is quite common for applications in usage behavior in various technological innovations (Davis et al., 1989). TAM concentrates on the benefits and perceived ease. Both of these components have a direct determining role in intention to use (Venkatesh and Davis, 2000). Based on the theory of reasoned action (TRA), Davis et al., (1989) have proposed a concept in TAM, stated that the intention to use and behavior of users to use a new system is determined by the ease of use and usefulness felt by users. (Tsai et al., 2014) in their study of consumer acceptance models for food and agriculture traceability systems in Taiwan revealed that perceived usefulness and ease factors had a positive effect on the intention to use. Another study conducted by (Hoque et al., 2015) has a difference with research conducted by (Tsai et al., 2014), in which his TAM model was used as a theoretical foundation. The result of a study conducted by (Hoque et al., 2015) revealed that perceived usefulness positively predicted intention to use mHealth services, while perceived ease of use was identified as an insignificant factor in intention to adopt technology services.

Effect of Subjective Norms on Intention to Use. Subjective norms can be seen from normative beliefs (support of others) and motivation to obey. Research by (Ghifarini et al., 2018) proves that there is a significant direct effect on intention i.e. subjective norms. While Yi et al., (2006) in his research shows that subjective norms have a significant effect on the intention to use. In this research, subjective norms are measured through people's thoughts and opinions about products resulting from technological innovations. 
Effects of Compatibility on Intention to Use. Compatibility is an Innovation Diffusion Theory model that has the most important effect on behavioral intentions to use (Wu and Wang, 2005). Research by (Zahidul et al., 2013) revealed that compatibility has a positive impact on influencing customers and that this factor is a key factor for using advanced mobile phone services (AMPS). This study proves that the relationship between AMPS and daily life, including work, education, social relations, and entertainment. Therefore, compatibility is very important when adopting a new system because it is related to individual work responsibilities and value systems, as well as experience using technology.

Effects of Perceived Self-Efficacy, and facilitating conditions for Intention to Use. Selfefficacy is measured by an indicator scale including self-confidence in managing a business, the leadership of human resources, mental maturity and ability to start a business (Gaddam, 2008). (Shafinah et al., 2018) in their research model based on the Technology Acceptance Model found that self-efficacy was proven to have a positive impact on interest in user behavior.

The effect of facilitating the conditions for intention to use. Future studies related to facilitating conditions that can predict the intention to use include research that has been done by (Teo, 2011). The result of his research found that facilitating conditions positively affects the behavioral intention of teachers to use technology. This explains that when the use of technology obtains adequate, accessible, timely, and relatively free technical support is considered to strengthen the intention to use technology.

Another study conducted by (Sharifzadeh et al., 2017) tried for the first time to apply an extended version of the Technology Acceptance Model (TAM) that combines innovation diffusion theory (IDT), perception of self-efficacy, and facilitating conditions to investigate the factors that influence farmer acceptance and use of Biological Control (BC) for rice stem borer control in rice fields. The result showed that the three external factors namely compatibility, perceived self-efficacy, and facilitating conditions had a strong influence on farmers' intention to use Biological Control (BC).

\section{METHODOLOGY}

The selection of research sites in the Garut Regency of West Java in four Subdistricts (Cikajang, Cisurupan, Cigedug, and Pasirwangi) during April-June 2019. The research design used was a survey of potato farmers. Data collection was carried out using face-toface interviews using questionnaire items. Sampling is done based on nonprobability sampling using convenience sampling techniques. Respondents in this study are potato farmers who have not used the median variety but know about the innovation product. Respondents were taken through this method as many as 120 farmers. According to (Hair et al., 2011) in the analysis of the Partial Least Square (PLS) Model the minimum number of respondents recommended ranges from 30 to 100 samples. But the number of samples that have been determined is more than the minimum number of respondents, so the number of samples of this study is considered to be sufficient.

The questionnaire is divided into two parts. The first part related to the characteristics of potato farmers includes 6 questions covering gender, age, education, agricultural 
income/year, farming experience, and land area. The second part measures farmers' perceptions of each variable in the model, where this section contains 32 indicator variables.

Table 2. Latent variables and indicator variables

\begin{tabular}{|c|c|c|}
\hline $\begin{array}{l}\text { Independent } \\
\text { Variable }\end{array}$ & Symbol & Indicator \\
\hline \multirow[t]{3}{*}{ Triability } & TRI 1 & Opportunity to show the trial result \\
\hline & TRI 2 & Try to plant in a small plot first before a bigger field \\
\hline & TRI 3 & Try to plant one harvest at a time \\
\hline \multirow[t]{3}{*}{ Observability } & OBS 1 & $\begin{array}{l}\text { It is not difficult to inform other farmers about the benefits of } \\
\text { using median varieties }\end{array}$ \\
\hline & OBS 2 & Able to produce more tubers \\
\hline & OBS 3 & Yields for processed potatoes look better \\
\hline \multirow{4}{*}{$\begin{array}{l}\text { Perceived Ease } \\
\text { of use }\end{array}$} & PEoU 1 & Resistant to pests so that it is easy in terms of plant care \\
\hline & PEoU 2 & Cultivation is easy to understand \\
\hline & PEoU.3 & Marketability \\
\hline & PEoU 4 & The ease of obtaining seeds \\
\hline \multirow{2}{*}{$\begin{array}{l}\text { Perceived } \\
\text { usefulness }\end{array}$} & PU 1 & Better than replaced varieties \\
\hline & PU.2 & The result can increase profits \\
\hline
\end{tabular}

\begin{tabular}{|c|c|c|}
\hline $\begin{array}{l}\text { Independent } \\
\text { Variable }\end{array}$ & Symbol & Indicator \\
\hline & PU.3 & High level of productivity \\
\hline & PU.4 & Potato seeds grow faster than other potato seeds \\
\hline \multirow[t]{6}{*}{$\begin{array}{l}\text { Subjective } \\
\text { Norms }\end{array}$} & SN 1 & $\begin{array}{l}\text { Agricultural extension workers are willing to use varieties of } \\
\text { medians. }\end{array}$ \\
\hline & SN 2 & The closest family thinks he should use the variety of medians \\
\hline & SN 3 & Fellow farmers recommend using varieties of medians \\
\hline & $\mathrm{SN} 4$ & $\begin{array}{l}\text { Willing to do what the agricultural instructor says to use varieties } \\
\text { of medians }\end{array}$ \\
\hline & SN 5 & $\begin{array}{l}\text { Willing to do what your closest relatives think about varieties of } \\
\text { medians }\end{array}$ \\
\hline & SN 6 & $\begin{array}{l}\text { Willing to follow the advice of fellow farmers to use varieties of } \\
\text { medians }\end{array}$ \\
\hline \multirow[t]{4}{*}{ Compatibility } & COM 1 & Having a match in the farmer's land \\
\hline & COM 2 & Suitable for processed food needs \\
\hline & COM 3 & No impact on the environment \\
\hline & COM 4 & Consistent with the farmers' financial situation \\
\hline \multirow[t]{4}{*}{$\begin{array}{l}\text { Perceived self- } \\
\text { efficacy }\end{array}$} & PSE 1 & $\begin{array}{l}\text { Farmers have the mental maturity for cultivating varieties of } \\
\text { medians }\end{array}$ \\
\hline & PSE 2 & $\begin{array}{l}\text { Farmers feel they have the skills and expertise to cultivate varieties } \\
\text { of medians }\end{array}$ \\
\hline & PSE 3 & Confidence in the ability to manage a business \\
\hline & $\mathrm{FC} 1$ & Technical guidelines support farmers in developing cultivation \\
\hline
\end{tabular}




\begin{tabular}{|c|c|c|}
\hline Facilitating & FC 2 & Special training workshops are available for farmers \\
\hline condition & FC 3 & $\begin{array}{l}\text { Procurement of special instructors can solve farmers' problems in } \\
\text { the field }\end{array}$ \\
\hline Intention to & IU 1 & Will use varieties of medians within six months \\
\hline Use & IU 2 & Would recommend varieties of medians to other farmers \\
\hline
\end{tabular}

Furthermore, respondents were given questions that were measured using a Likert scale of scores $1-5(1=$ strongly disagree, $2=$ disagree, $3=$ doubtful, $4=$ agree, $5=$ strongly agree). The analysis used in this research is descriptive analysis and SEM analysis. Descriptive analysis is used to analyze the characteristics of respondents and the level of potato farmers' acceptance of the intention to use varieties of medians. While the Structural Equation Model (SEM) analysis is used to test the effect of exogenous variables on endogenous variables. The development model framework in this study is presented in Figure 1.

Figure 1. Framework for research development models

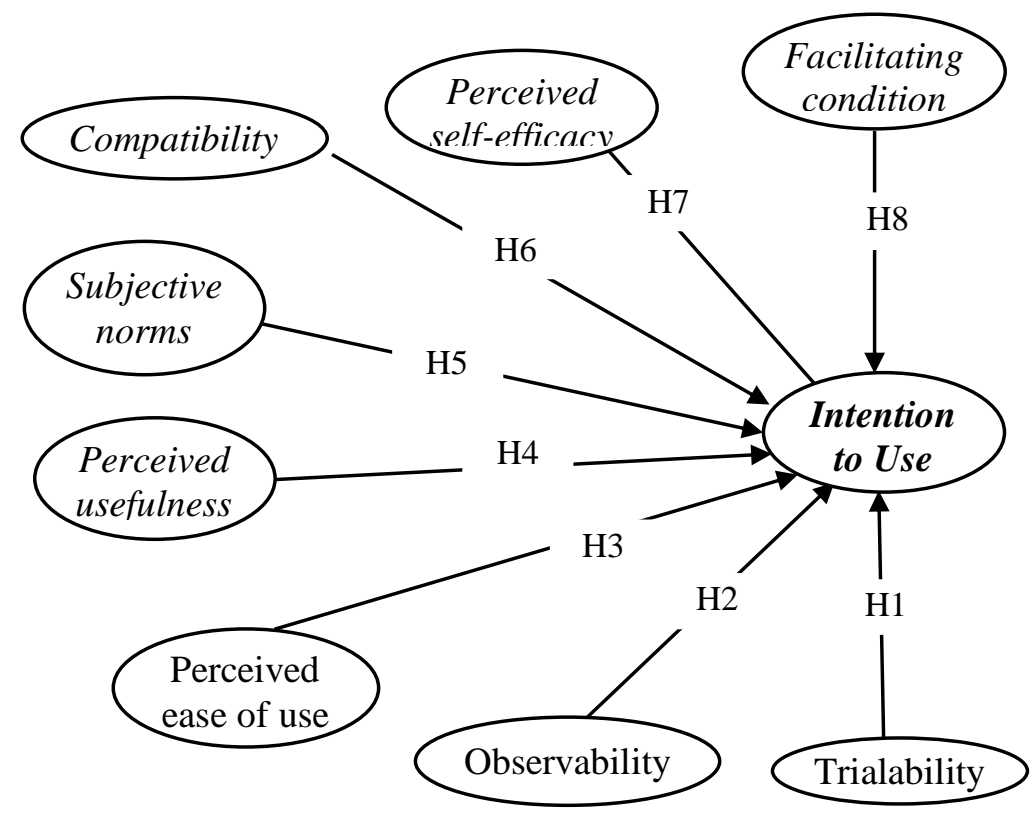

Based on the above research model framework, the following hypotheses can be formulated:

H1: The ability of the trial has a positive effect on the intention to use.

$\mathrm{H} 2$ : Can be seen as having a positive effect on the intention to use.

H3: The perceived ease of use has a positive effect on the intention to use.

$\mathrm{H} 4$ : The perceived usefulness has a positive effect on the intention to use.

H5: Subjective norms have a positive effect on the intention to use.

H6: Compatibility has a positive effect on the intention to use.

H7: Self-perceived efficacy has a positive effect on the intention to use. 
H8: Facilitation conditions have a positive intention to use.

\section{RESULT AND DISCUSSION}

Characteristics of Respondents. Characteristics based on gender indicate that the number of potato farmers with male sex is far greater than those of female sex. One of the reasons for this is that the majority of potato farmers, as previous farmers, passed down their farming businesses to boys. This result is by the research of (Ademola et al., 2014) stated that tuber farmers are dominated by male farmers rather than female farmers. Characteristics of respondents based on the age of the majority are in the age range between 41 - 50 years. This showed that respondents in that age range are included in the late adopter category of innovations. (Egge et al., 2010) in their study showed that farmers who find it difficult to adopt new findings have an average age of 41.4 years. However, due to their large number, market education is needed in this segment to influence the interest in adopting technological innovations.

The formal education of farmers is still relatively low, with $43.8 \%$ only graduating from elementary school. This condition showed that potato farmers in running their farming businesses are less aware of the importance of education in developing agricultural businesses. While the average annual income of farmers in this group is 104.12 million rupiahs. The majority of potato farmers have income greater than 100 million per year. This showed that potato farmers are included in the category of having a large income. (Hadimartono et al., 2017) in their study stated that agriculture carried out by farmers, in general, is a big effort to earn income. These characteristics indicated that farming in the study area most of the respondents consider farming as the main business. The connection, in this case, varieties of medicinal products are expected to be easier to promote, because it can be a new business opportunity for farmers.

Characteristics of respondents based on farming experience show that most farmers have experience of 1-10 years with an average of 18 years of farming. The experience will be considered by farmers in adopting innovations. Farmers who have long farming experience are considered to be better and faster in recognizing new technologies by considering the successes and failures of the past than farmers who have less experience (Faizaty et al., 2016). However, in this study the experience of farmers in potato cultivation was relatively lacking, causing farmers to be slow to recognize the median varieties resulting from this technological innovation.

The area of potato farmers in this group is at most between $0.1-1$ ha $(71.7 \%)$. This showed that potato farmers in this region who have not used the seeds of the Medians variety include small scale farmers with narrow land ownership. This result is different from a study conducted by (Pusdima et al., 2018) which showed that farmers adopting technology have an area of $>2$ ha. This means that these conditions proved that farmers who have large tracts of land will find it faster and easier to adopt new technologies. While farmers with small landholdings tend to maintain existing cropping patterns. This condition is due to the thought of large risks and uncertainty of production and marketing that might occur if you choose to adopt innovations (Theresia et al., 2016). 
Table 3. Characteristics of Potato Farmers

\begin{tabular}{lcc}
\hline \multicolumn{1}{c}{ Characteristics } & Number of Farmers & Percentage (\%) \\
\hline Gender & 117 & 97,5 \\
Male & 3 & 2,5 \\
Female & 9 & \\
\hline Age & 36 & 7,5 \\
$20-30$ & 49 & 30 \\
$31-40$ & 26 & 40,8 \\
$41-50$ & & 21,7 \\
$>$ 50 & 56 & \\
\hline Education & 39 & 46,7 \\
Elementary & 22 & 32,5 \\
Junior High School & 3 & 18,3 \\
Senior High School & & 2,5 \\
Bachelor Degree & 18 & 15,0 \\
Income/ year & 30 & 25,0 \\
$5-30$ million/year & 34 & 28,3 \\
$31-60$ million/year & 38 & 31,7 \\
$61-100$ million/year & & \\
$>$ 100 million/year & 44 & 36,7 \\
\hline Farming experience & 37 & 30,8 \\
$1-10$ year & 33 & 27,5 \\
$11-20$ year & 6 & 5,0 \\
$21-40$ year & 86 & 18,7 \\
$>$ 40 year & 22 & 10,0 \\
\hline Land area0,1 - 1 ha & 12 & \\
$1,1-2$ ha & & \\
$>$ 2 ha & &
\end{tabular}

The intention of Non-Medians Farmers' Acceptance of Medians Potato Variety Products. The level of acceptance of the intention of farmers to use potato products of the varieties of medians resulting from agricultural technology innovation, most of the potato farmers tend to still have doubts about these products. This level of doubt is shown by the fact that more farmers make more choices, they will probably use potato varieties of medians in the next 6 months $(42.5 \%)$ compared to those who make choices "yes" $(12.5 \%)$ and it is very likely $(22.5 \%)$ to use this innovative product. However, most potato farmers would recommend the Medians potato variety product to other farmers, because the statement yes would recommend higher (33.3\%) compared to other statements \{ no $(3.3 \%)$, not possible $(10.8 \%)$, maybe $(32.5 \%)$ ), it is very possible $(20 \%)\}$. Indicators of potato farmers' acceptance intentions for these varieties are shown in Figure 2 below. 
Figure 2. The intention of product acceptance for varieties of medians

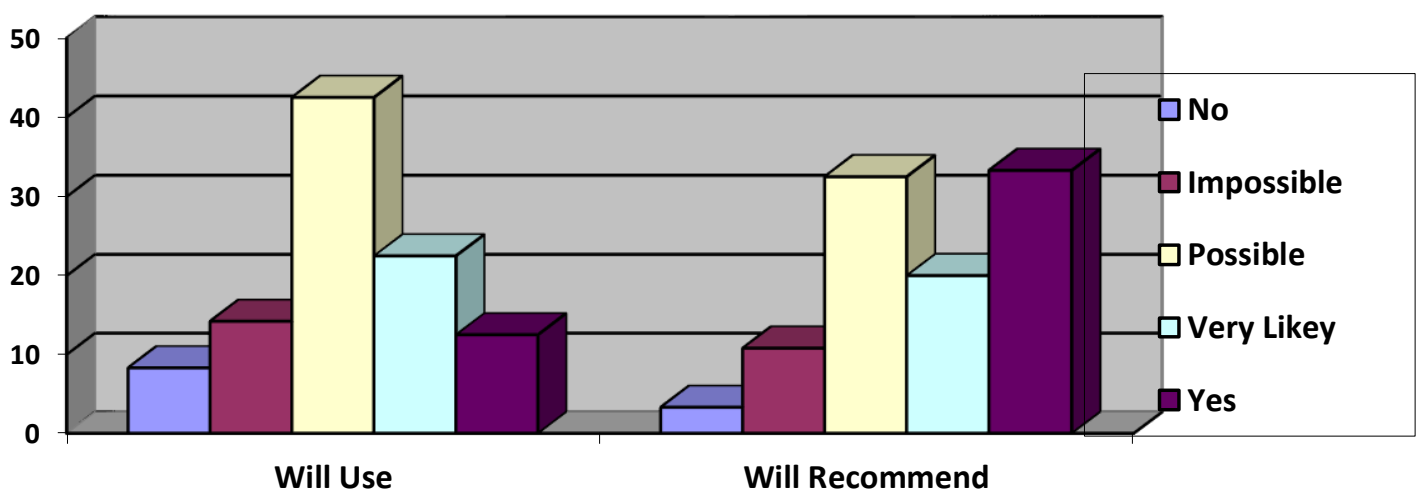

Source: (Processed by the author, 2019)

Outer Model Analysis. This analysis is conducted to see the relationship between latent variables and indicator variables by first measuring convergent validity. The loading factor is an initial report in the convergent validity test. The loading factor value which has a high level of validity is one that has a value greater than 0.7 (Latan and Ghozali, 2015). The result of processing with smart PLS showed that there are 11 indicators in the initial SEM model that have a loading factor value of less than 0.7 . Therefore the model needs to be estimated again by issuing these indicators. However, the value of the loading factor 0.683 on the facilitating condition indicator (X81) can still be tolerated and is still used to measure latent variables. This is caused even though the re-estimation result without issuing indicators are worth 0.683 . However, this value has shown an outer loading coefficient above 0.7. Hence, the total indicators issued in the initial model of the study were 10 indicators. After 10 indicators are issued in the model, the validity test has resulted in a loading factor value exceeding 0.7 for all indicator variables. This means that the model has a good convergent validity value. The final evaluation result of the measurement model (outer model) can be shown in Figure 3. 
Figure 3. The final framework of the SEM model

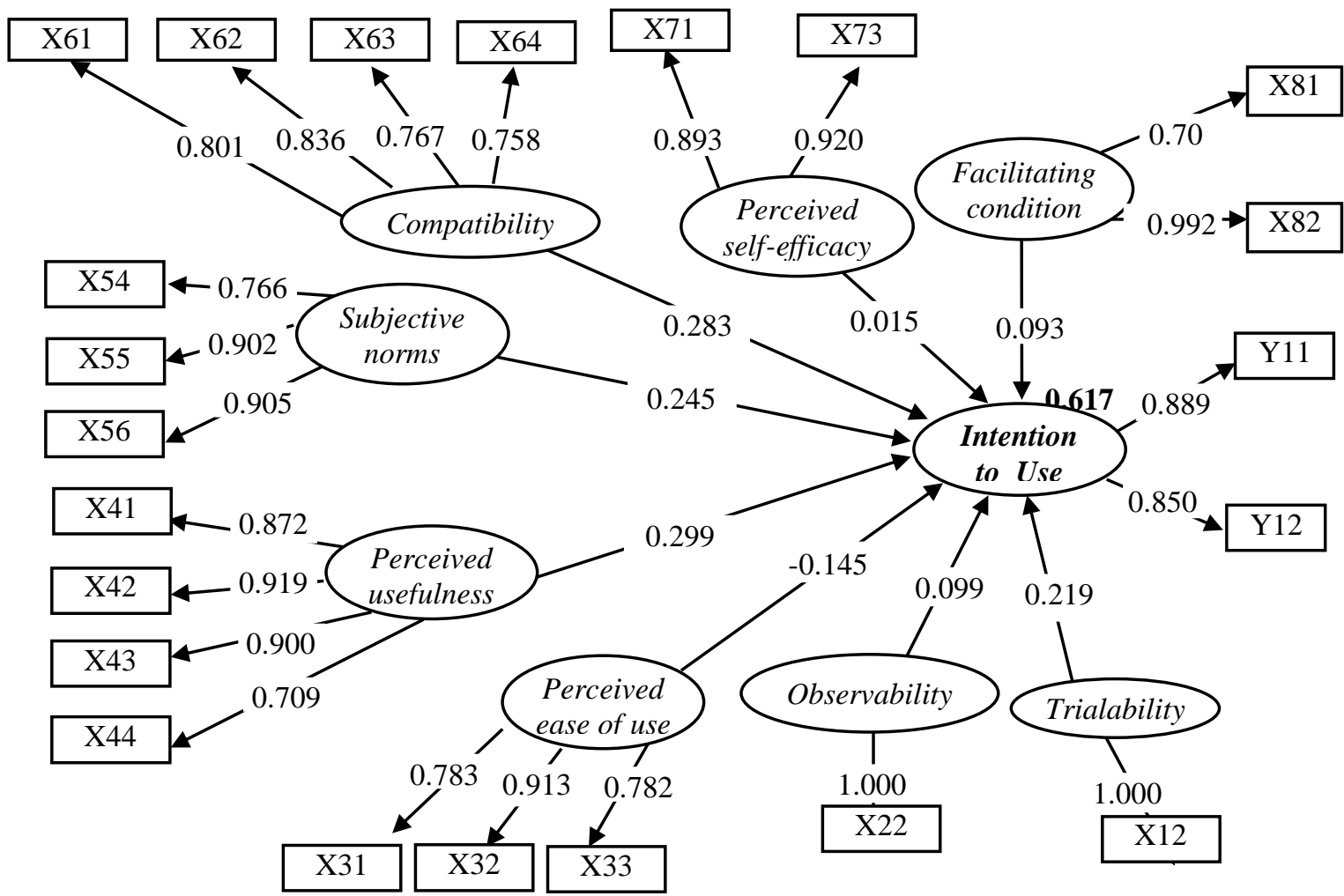

The result of retesting the discriminant validity test produced a cross-loading value and the root AVE. The results of this study indicate that all variables have a cross-loading value for each variable above 0.7. For the roots of Average Variance Extracted (AVE), according to (Ghozali, 2014), a good AVE is required to have a value greater than 0.5 . The square root values for AVE for each construct are presented in Table 4.

Table 4. Correlations between Constructions and Square Root Value AVE

\begin{tabular}{lccccccccc}
\hline & IU & Co & FC & Ob & PEOU & PSE & PU & SN & Tr \\
\hline Intention to use & 0,870 & & & & & & & & \\
$\begin{array}{l}\text { Compatibility } \\
\text { Facilitating }\end{array}$ & 0,689 & 0,791 & & & & & & & \\
condition & 0,153 & 0,128 & 0,861 & & & & & & \\
$\begin{array}{l}\text { Observability } \\
\text { Perceived ease of }\end{array}$ & 0,292 & 0,234 & 0,079 & 1,000 & & & & & \\
use & 0,622 & 0,801 & 0,104 & 0,230 & 0,829 & & & & \\
Self-efficacy & 0,609 & 0,786 & $-0,045$ & 0,216 & 0,783 & 0,906 & & & \\
$\begin{array}{l}\text { Perceived } \\
\text { usefulness }\end{array}$ & 0,705 & 0,816 & 0,060 & 0,258 & 0,875 & 0,789 & 0,854 & & \\
$\begin{array}{l}\text { Subjective norms } \\
\text { Triability }\end{array}$ & 0,562 & 0,500 & 0,030 & 0,234 & 0,552 & 0,502 & 0,601 & 0,860 & \\
\hline & 0,511 & 0,499 & 0,027 & 0,070 & 0,454 & 0,497 & 0,510 & 0,194 & 1,000 \\
\hline
\end{tabular}


Based on the table in this study, the value of AVE square root in each construct has exceeded 0.5 . Thus the model has good discriminant validity.

Next for the reliability test that is by showing the value of composite reliability and Cronbach's alpha in each latent variable (construct). According to (Jogiyanto, 2015) the rule of thumb of composite reliability and Cronbach's alpha values is expected to be greater than 0.7 , but the value of 0.6 is still acceptable. Based on the result of processing, the reliability test evaluation was fulfilled because the composite reliability and Cronbach's alpha values were greater than 0.6 (Table 5).

Table 5. Value of composite reliability and Cronbach alpha

\begin{tabular}{clcc}
\hline No & \multicolumn{1}{c}{ Latent Variable } & Composite Reliability & Cronbach's Alpha \\
\hline 1 & Trialability & 1.000 & 1.000 \\
\hline 2 & Observability & 1.000 & 1.000 \\
\hline 3 & Perceived ease of use & 0.867 & 0.771 \\
\hline 4 & Perceived usefulness & 0.914 & 0.873 \\
\hline 5 & Subjective Norms & 0.894 & 0.825 \\
\hline 6 & Compatibility & 0.870 & 0.801 \\
\hline 7 & Perceived self-efficacy & 0.902 & 0.783 \\
\hline 8 & facilitating condition & 0.848 & 0.758 \\
\hline 9 & Intention to Adoption & 0.861 & 0.680 \\
\hline
\end{tabular}

Inner Model Evaluation. In the inner part of this model, it is predicted that endogenous intention to use variables are directly affected by exogenous variables. The parameters used for evaluating the inner model are the determinant coefficient (R) and t-statistic. The result of data processing in smart PLS showed that the R-value for the behavioral intention to use is 0.6170 meaning that $61.70 \%$ of the intention to use variable can be explained moderately and strongly by exogenous latent variables. While the remaining $38.30 \%$ is explained by other variables outside the model in this study. The next $\mathrm{R}$-value is used to measure the goodness of the Goodness of Fit $(\mathrm{GoF})$ model. Goodness of Fit calculation result obtained a value of 0.7477 . So that the model in this study is included in both categories.

Hypothesis testing. In this research, the hypothesis used is a two-tailed hypothesis by calculating bootstrapping on the path coefficient that is by comparing t-counts with t-tables. If t-count is greater than t-table (1.96) the results show the hypothesis is accepted, but if $t$ count is less than t-table (1.96) then the hypothesis formulation is rejected. The bootstrapping values are presented in table 6 . 
Table 6. The bootstrapping result

\begin{tabular}{|c|c|c|c|c|c|}
\hline Variables & $\begin{array}{l}\text { Original } \\
\text { Samples }\end{array}$ & $\begin{array}{c}\text { Sample } \\
\text { averages }\end{array}$ & $\begin{array}{l}\text { Standard } \\
\text { Deviation }\end{array}$ & $\begin{array}{c}\mathbf{P} \\
\text { Values }\end{array}$ & $\begin{array}{c}\mathbf{T} \\
\text { Statistics }\end{array}$ \\
\hline Trialability -> Intention to Use & 0.219 & 0.217 & 0.073 & 0.003 & $3.003 * *$ \\
\hline Observability -> Intention to Use & 0.099 & 0.092 & 0.061 & 0.104 & 1.629 \\
\hline $\begin{array}{l}\text { Perceived ease of use -> Intention } \\
\text { to Use }\end{array}$ & -0.145 & -0.138 & 0.167 & 0.387 & 0.865 \\
\hline $\begin{array}{l}\text { Perceived usefulness -> Intention to } \\
\text { Use }\end{array}$ & 0.299 & 0.294 & 0.143 & 0.036 & $2.099 * *$ \\
\hline $\begin{array}{l}\text { Subjective norms -> Intention to } \\
\text { Use }\end{array}$ & 0.245 & 0.251 & 0.073 & 0.001 & $3.355 * *$ \\
\hline Compatibility $->$ Intention to Use & 0.283 & 0.292 & 0.119 & 0.018 & $2.383 * *$ \\
\hline $\begin{array}{l}\text { Perceived self-efficacy -> Intention } \\
\text { to Use }\end{array}$ & 0.015 & 0.005 & 0.110 & 0.894 & 0.133 \\
\hline $\begin{array}{l}\text { Facilitating condition -> Intention } \\
\text { to Use }\end{array}$ & 0.093 & 0.095 & 0.067 & 0.165 & 1.389 \\
\hline
\end{tabular}

H1 Effect of trialability on the intention to use. Table 4 showed the first hypothesis Tstatistic value of (3.003). This value is greater than the T-table (1.96). This means that the hypothesis is accepted, so it can be concluded that trialability has a positive effect on the intention to adopt. This finding is following previous research conducted by (Ajili et al., 2012), and (Hasan et al., 2018), who stated that the Triability variable has the effect of intention to use. This result indicated that the more innovative products of potato varieties medians can be tested on the small size, the higher the intention of farmers to use. Potato farmers in the case of the trial of this product expect to do experiments on small scale land first before trying on a larger scale land. Experiments on the innovation of agricultural products on a small scale are expected to minimize losses. However, if the trials carried out by farmers are proven to be able to improve the quality of agricultural products will have a great opportunity to reuse.

H2 Effect of Observability on the intention to use. Table 4 shows the T-statistic value in the second hypothesis $(1,629)$. This value is smaller than the T-table value (1.96). This means that the hypothesis is rejected, so the observability variable harms intention to use or adapt. This finding is not following the results of research by (Shiau and Chau, 2015) which revealed that observability has a positive effect on the intention to use. The indicator of the observability variable illustrates that potato varieties of medians are varieties that can produce more tubers per plant than other potato varieties. The ability of medians to produce more tubers is not a factor in determining farmers' intention to use. Potato farmers in observing the seeds of varieties of medians assume that this product has advantages. That is because the partner company of the Indonesian Agency for Agricultural Research and Development as a seed producer has experienced in creating a median variety of seeds since this variety was introduced to potato farmers in Garut Regency.

H3 the effect of perceived ease of use on the intention to use. Table 4 showed the Tstatistic value in the third hypothesis of (0.865). This value is lower than the T-table value 
(1.96). This means that the hypothesis is rejected, so it can be concluded that the perceived convenience variable does not affect the intention to use. This variable is by research by (Hoque et al., 2015) which revealed that perceived ease of use is a factor that does not influence the intention to adopt the technology. This result indicated that perceived ease of use indicators do not affect farmers' intention to use. The first indicator is that farmers want varieties of medians resistant to disease pests so that it makes it easier in terms of plant care. This condition farmers are not familiar with the advantages of the potato varieties medians related to varieties that are resistant to pests. The second indicator is the cultivation of varieties of medians more easily understood. Farmers still consider that cultivating potato median varieties has similarities with the cultivation of other potato varieties. The third indicator is easy to market yields. This condition farmers cannot access the market. They are only limited to seeing that the potato market is a traditional market, while the potato market opportunity can be extended to modern and industrial markets.

H4 the effect of perceived usefulness on the intention to use. In contrast to the result of the previous hypothesis, Table 4 showed the fourth hypothesis T-statistic value of $(2,099)$. The value of this hypothesis is accepted because it is greater than the T-table (1.96). It can be concluded that the perceived usefulness variable has a positive effect on the intention to use. The result of this research has in common the result of previous researchers namely (Tsai et al., 2014) and (Zahidul et al., 2013) showed that the perceived usefulness show a positive effect on the intention to use. These findings reveal that all indicator variables influence the intention to use. The first indicator is that potato varieties medians for farmers better than substitute varieties. This condition farmers expect the potato tubers produced by the varieties of medians are superior to the previous varieties. Also, farmers want potato seeds produced by this variety to produce quality seeds that have a longer shelf life than other varieties of seeds. The second indicator is the use of median varieties for farmers the results can increase financial returns. The financial benefit expected by farmers is to realize an increase in their farm income when using potato varieties medians. The third indicator is the median potato has a high level of productivity. In other words, farmers' hope that for the yield of each area of land used for the cultivation of this variety must be able to produce higher levels of production than other processed potato production. Next, the fourth indicator is the median potato variety for seed growth is expected to be faster than other potato seeds. When the seeds grow fast, the thing that is prioritized by farmers is to speed up the planting time on their farm.

H5 Effect of subjective norms on the intention to use. Table 4 showed the T-statistic value for the fifth hypothesis $(3,355)$. This value is higher than the T-table (1.96), so it can be concluded that the subjective norm variable has a positive effect on the intention to use. The result in this study is by previous studies conducted by (Nurjaman et al., 2015) and (Yi et al., 2006) revealed that the subjective norm variables influence the intention to use or adapt. In the subjective norm variable, 3 indicators reflect potato farmers which can influence the intention to use potato varieties medians. The three indicators are farmers who want to do what the instructor says, farmers want to do what their closest relatives think, and farmers want to follow the advice of their fellow farmers to use the median variety of potatoes. This is a component formed by the motivation to obey farmers about the extent to which parties are considered important by them. 
H6 Effect of compatibility on the intention to use. Table 4 above showed the T-statistic value for hypothesis six (2,046). This value is higher than the T-table (1.96). This means that the hypothesis is accepted, so it can be concluded that the compatibility variable has a positive effect on the intention to use. This finding is by research conducted by (Sharifzadeh et al., 2017) and (Zahidul et al., 2013) which revealed that compatibility influences intention to use. Compatibility variables have 4 indicators that can all reflect these variables. The first indicator is the suitability of varieties on the farm. In using the median variety of potato seeds, potato farmers have an expectation of compatibility with their agricultural land. Suitability of land for cultivation affects the development and success of the cultivation of this variety of potatoes. The more suitable the varieties planted on the farmer's land the higher the intention of the farmers to use. The second indicator is the suitability of the need for processed food. The more suitable the medians potatoes for processed food needs the higher the intention of farmers to use. The third indicator is the use of the median variety of potatoes does not harm the environment. In this case, farmers hope that cultivation using median varieties will not pollute the environment such as damaging soil elements, waterways, and the spread of other plant viruses. The more innovative products used have friendliness in the environment the more farmers have the intention to use. While the last indicator is the cultivation of potatoes using varieties of medians consistent with the financial situation of farmers. It was revealed that the more suitable the innovation products used with the financial situation of farmers would increase the influence of intention to use. In other words, farmers expect that cultivation using this variety must tend to be more efficient and able to reduce farmers' expenditure costs.

H7 Effect of perceived self-efficacy on the intention to use. Based on Table 4 above hypothesis seven is rejected (0.133). That is, perceived self-efficacy variables do not affect the intention to use. The findings of this study are not by research conducted by (Shafinah et al., 2018) and (Sharifzadeh et al., 2017) revealed that perceived self-efficacy is a factor that positively influences intention to use technology. The insignificant result of this variable is because potato farmers lack mental maturity and confidence in the ability to manage the median variety of potato cultivation. This condition is due to farmers not having special skills and expertise when using this variety for cultivation. Non-partner farmers still consider the cultivation pattern of potato varieties medians not much different from other types of potato varieties. Therefore partner companies of the Agency for Agricultural Research and Development must learn how to motivate farmers to improve their abilities. It is strived for farmers to become more skilled and able to achieve success in cultivating these varieties of medians potatoes.

H8 Effect of facilitating conditions on the intention to use. Table $4 \mathrm{~T}$-statistics values of the eight hypotheses were rejected $(1,389)$. This is because the value is lower than the Ttable value (1.96). That is, the facilitating condition variable does not affect the intention to use. The result is not by research conducted by (Teo, 2011) and (Sharifzadeh et al., 2017) which proved that the facilitation conditions positively influence the intention to use technology. The facilitating condition variable consists of two indicators that are maintained in the model, namely the provision of technical guidance for development and cultivation, and the provision of special training in the cultivation of median potato varieties for farmers. These two indicators do not affect the intention to use. This is due to the low knowledge of 
farmers in the technical guidelines provided by partner companies. Besides, non-partner potato farmers are less involved in technical training (training workshops) for cultivation development.

Managerial Implications. Managerial implications in this study can be used as input or recommendations for partner companies of the Indonesian Agency for Agricultural Research and Development (PT. CHAMP) as a company commercializing the potato varieties of medians resulting from technological innovation. Based on the acceptance analysis, the intention of farmers to use the potato varieties of the majority of medians tends to still have doubts about the innovation product. This is due to the low level of assessment by farmers in determining the intention to use this product within the next six months. So that partner companies need a strategic step that is focused on the factors that influence the intention of farmers to use include triability, perceived usefulness, subjective norms, and compatibility.

Based on the analysis of the Structural Equation Model Partial Least Square (SEM PLS) the trialability variable has a positive effect on the intentions of farmers using potato varieties medians. Indicator of variable trialability means it influences on increasing farmers' intention to use. An indicator that partner companies need to pay attention to is the farmer conducting trials to plant potato medians on small scale land first before on a larger scale. This is done to minimize losses in the event of failure. But to avoid this, the partner companies need to conduct intensive supervision of potato farmers who are willing to try to plant medians on their farms. Supervision is carried out to maintain the quality produced so that the medians potato products get a good rating from farmers. According to (Kotler, 2009), consumers try innovation products to increase the estimated value of a product.

Intentions to use based on perceived usefulness, partner companies must be able to realize indicators on this variable, namely median potato product varieties are better than varieties that are replaced, the results can increase profits, have a high level of productivity and seed growth faster than other potato seeds to speed up time planting. To realize this, the company needs to improve the performance of the technical, laboratory and marketing teams. In this case, the technical team focuses on productivity, the laboratory team focuses on creating superior seeds, and the marketing team focuses on helping farmers to market their products in hopes of increasing their farm income.

Furthermore, the intention to use based on subjective norms, where this variable is the most influential to determine the intention of farmers to adopt potato varieties medians. Under these conditions, partner companies need to understand that subjective norms refer to other people's perceptions that are important to consumers who influence their decisions to determine their behavior. The thing that must be understood by partner companies so that this product is accepted among farmers is that it must pay attention to subjective norm indicators. This indicator is formed based on a sense of motivation to obey them, among others, farmers want to do what the instructor stated, farmers want to do what close relatives think, and farmers want to follow the advice of fellow farmers to use median varieties. Also, it is always coordinating with the government to provide support and participate in promoting this product through the domestic product love movement.

In addition to subjective norms, intention to use is positively influenced by compatibility factors. In this case, partner companies must meet the needs of farmers following the values that exist as potential adopters to receive this innovative product. The 
needs of potential farmers in this variety are on the indicators namely suitability to agricultural land, suitability to the need for processed food, does not harm the environment and is consistent with the financial situation of farmers. This need can be optimized by partner companies by increasing their business performance activities. Activities that must be carried out are conducting and determining the schedule of monitoring and evaluation in the field to determine the development of farmers during cultivation using varieties of medians products. This is a competitive strategy that partner companies must consider. With this strategy, it is expected to drive to increase productivity, satisfy its customers, and ultimately lead to the reuse of this technological innovation product.

\section{CONCLUSION}

Conclusion. The intention of the potato farmers' acceptance of the potato products of the Medians variety, the majority of technological innovations, stated that they will use the product within the next 6 months. However, most potato growers will recommend this product to other farmers. The intention of farmers to adopt the median potato variety is positively influenced by triability, perceived usefulness, subjective norms, and compatibility variables. Whereas observability, perceived ease of use, perceived selfefficacy, and facilitating conditions variables did not have a positive effect on farmers' intention to use.

Suggestion. The intention to adopt the median potato variety should be improved from the aspect of product trials, perceived usefulness, subjective norms, and product suitability. So those farmers in the Garut Regency of West Java are motivated to use these technological innovations. Further research can be developed by including other variables that do not yet exist in this study include farmers' attitudes, perceived behavioral control, and perceived value.

\section{REFERENCES}

[BPS]. Badan Pusat Statistik Kabupaten Garut. (2017). Garut Dalam Angka. Kabupaten Garut. 191-204.

Ademola, A. A., Walter, S.A., and Bamidele, O.S. (2014). Potential Benefits Of Genetic Modification (GM) Technology For Food Security And Health Improvement In West Africa: Assessing the perception of farmers in Ghana and Nigeria. African Journal of Biotechnology 13 (2): 245-256.

Ajili, A., Salehi, S., Moghaddam R.K., Hayati, D., and Karbalaee, F. (2012). Estimating The Model Of Investigating Attitude And Intention In The Usage Of Variable Rate Irrigation Technology. American Journal of Experimental Agriculture 2 (3): 542-556.

Ajzen, I. (1991). The Theory Of Planned Behavior. Organizational Behavior and Human Decision Process 50: 179-201

Bandura, A. (1977). Self-Efficacy: Toward A Unifying Theory Of Behavioral Change. Psychol. Rev. 84. 191-215.

Buletin Konsumsi Pangan. (2017). [internet]. [diakses 26 Oktober 2018]. Tersedia pada http://epublikasi.setjen.pertanian.go.id/epublikasi/buletin/konsumsi/2017/. 
Buletin_Konsumsi_Pangan_Semester_2_2017/files/assets/basic-html/page41.html. conceptual model of utilization. MIS Quart 15: 125-143.

Davis, F.D., Bagozzi, R.P, Warshaw P.R. (1989). User acceptance of computer technology: a comparison of two theoretical models. Management Science 35 (8): 982-1003 doi.org/10.1016/j.cropro.2017.01.014.

Egge, M., Pichai, T., and Rangsipaht, S. (2010). Factors Influencing The Adoption Of Improved Sorghum Varieties In Awbere District Of Somali Regional State. Ethiopia. East African Journal of Sciences 4 (1): 41-47.

Everett, M., and Rogers. (2003). Elements of diffusion. Diffusion of innovations, 5(2003): $1-38$.

Faizaty, E.F., Rifin, A., Netti, T. (2016). Proses Pengambilan Keputusan Adopsi Inovasi: Teknologi Budidaya Kedelai Jenuh Air (Kasus: Labuhan Ratu Enam, Lampung Timur). Jurnal Agraris 2(2): 97-106.

Fishbein, M., and Ajzen, I. (2010). Predicting and changing behavior: The reasoned action approach. New York, US: Psychology Press.

Gaddam. (2008). Identifying The Relationship Between Behavioral Motives and Entrepreneurial Intention: An Empirical Study Based Participations of Business Management Students. The Icfaian Journal of Management Research 7: 35-05.

Ghifarini, F.A., Sumarwan, U., Najib, M. (2018). Application Of Theory Of Planned Behavior In Shrimp Consumer Behavior Analysis. Independent Journal of Management and Production. 9 (3): 984-1001.

Ghozali, I. (2014). Structural equation modeling: Metode alternatif dengan Partial Least Square(PLS). Semarang (ID): Badan Penerbit Universitas Diponegoro.

Hadimartono, S., Sumarwan, U., and Sanim, B. (2017). Analysis Of Re-Purchase Intention By Hybrid Rice Seed Farmers. Journal of Consumer Sciences 02 (01): 1-12.

Hair, F.J., Sarstedt, M., Ringle, M.C., and Mena, J.A. (2011). An Assessment Of The Use Of Partial Least Squares Structural Equation Modelling In Marketing Research. Journal of Academy of Marketing Science 40 (1): 414-433.

Hasan, R., Lowe, B, and Petrovici, D. (2018). Consumer Adoption Of Pro-Poor Service Innovations In Subsistence Marketplaces. Journal of Business Research, Pages 1-15.

Hernandez, J. M. C., and Mazzon, J. A. (2007). Adoption of internet banking: Proposition and implementation of an integrated methodology approach. The International Journal of Bank Marketing. 25: 72-88.

Hoque, R.M., Karim, R.M., and Amin, B.M. (2015). Factors Affecting The Adoption Of Mhealth Services Among Young Citizen: A Structural Equation Modeling (SEM) Approach. Asian Business Review. Volume 5 Issue 11.

Hsbollah, H. M, Idris, K. M. (2009). E-learning adoption: The role of relative advantages, trialability, and academic specialization. Campus-Wide Information Systems 26: 5470 .

Jogiyanto, H., Abdillah, W. (2015). Partial Least Square (PLS) - Alternatif Structural Equation Modeling (SEM) Dalam Penelitian Bisnis. Yogyakarta (ID): ANDI.

Kotler, P., Keller, K.L. (2009). Manajemen Pemasaran. Ed ke-13. Jilid 2. Jakarta (ID): Erlangga.

Latan, H., dan Ghozali, I. (2015). Partial Least Squares Konsep, Teknik dan Aplikasi Menggunakan Program SmartPLS 3.0. Semarang (ID): Badan Penerbit-Undip. 
Lee, A.Y.K., and Mok, W.K. (2013). A case study on the application of the theory of planned behavior: Predicting physical activity of adolescents in Hongkong. Journal Community Medical Health Education 3(5): 231.

Lee, Y.H., Hsieh, C.Y., and Hsu, N.C. (2011). Adding innovation diffusion theory to the technology acceptance model: Supporting employees' intention to use e-learning systems. Educational Technology and Society 14 (4): 124-137.

Legris, Ingham, P., and Collerette, J. (2003). Why do people use information technology? A critical review of the technology acceptance model. Inf. Manag. 40.

Marakas, G.M., Johnson, R.D., Clay, P.F. 2007. The evolving nature of the computer selfefficacy constructs: An empirical investigation of measurement construction, validity, reliability, and stability over time. Journal Association Information Systems 8: 16-46.

Nurjaman, Sumarwan, U., dan Kirbrandoko. (2015). Perilaku Dunia Usaha dalam Melakukan Adopsi Inovasi Pertanian. Jurnal Bisnis dan Manajemen 16 (01): 29-37.

Pusdima, R.P. Siswanto, I.S, and Wiludjeng, R. (2018). Technology Adoption Level Of True Shallot Seed In Klambu Sub-District, Grobogan Regency. AGRARIS: Journal of Agribusiness and Rural Development Research 4 (1): 9-17.

Saade R., Bahli B. (2005). The impact of cognitive absorption on perceived usefulness and perceived ease of use in on-line learning: an extension of the technology acceptance model. Journal Information and Management 42 (02): 317-327.

Shafinah, K., Ribka. A., Noraidah S., Amelia, N.A.W., and Riza S. (2018). Pengembangan dan Evaluasi Model Keinginan Menggunakan Aplikasi Mobile Pencegahan Penyakit Tanaman Lada Hitam. Jurnal Manajemen 17 (52): 207-219.

Sharifzadeh, S.M., Damalas, A.C., Abdollahzadeh, G., and Gorgi, A.H. (2017). Predicting adoption of biological control among Iranian rice farmers: An application of the extended technology acceptance model (TAM2). Crop Protection.

Shiau, W.L., and Chau P.Y.K. (2015). Understanding behavioral intention to use a cloud computing classroom: Multiple model-comparison approaches. Information and Management (2015), http://dx.doi.org/10.1016/j.im.2015.10.004.

Suryani, L., Putra, S.T.E., and Dianawati, M. (2017). The influence of aggregate hydroponic planting media composition to G0 seeds production of three potato cultivars (Solanum Tuberosum L.). Journal of Vegetalika 6 (2): 1-13.

Syakir, M. (2015). Pemantapan Inovasi dan Diseminasi Teknologi dalam Memberdayakan Petani. Jakarta (ID): Badan Penelitian dan Pengembangan Pertanian.

Teo, T. (2011). Factors Influencing Teachers' Intention Intention To Use Technology: Model Development and Test. Computer and Education 57: 2432-2440.

Theresia, V., Fariyanti, A., and Tinaprilla, N. (2016). Pengambilan Keputusan Petani Terhadap Penggunaan Benih Bawang Merah Lokal dan Impor di Kabupaten Cirebon, Jawa Barat. AGRARIS: Journal of Agribusiness and Rural Development Research 2 (1): 50-60. DOI.org/10.18196/agr.2125.

Thomson, R.L., Higgins, C.S., Howell, J.M. 1991. Personal computing: Toward a

Tsai, T.H., Hong, T.J., Yeh. P.S., and Wu. J.T. (2014). Consumers' acceptance model for Taiwan agriculture and food traceability system. International Journal of Contemporary and Applied Studies of Man. 17(3): 845-856.

Venkatesh, V., and Davis, D.F. (2000). A Theoretical Extension of the Technology Acceptance Model: Four Longitudinal Field Studies. Management of Science. 46 (2): 186-204. 
Wu, H., Wang, C. (2005). What drives mobile commerce? An empirical evaluation of the revised technology acceptance model. Information and Management 42: 719-729. DOI :10.1016/j.im.2004.07.001.

Yi, Y.M., Jackson, D.J., Park, S.J., Probst, C.J. 2006. Understanding information technology acceptance by individual professionals: Toward an integrative view. Information and Management 43:350-363. DOI:10.1016/j.im.2005.08.006.

Zahidul, Md., Low, C.K.P., and Hasan, I. (2013). Intention to use advanced mobile phone services (AMPS). Management Decision 51 (04): 824-838. 